\title{
FOR A CONSCIUOS FRUITION OF THE CULTURAL HERITAGE OF ANCIENT NOTO (SICILY). EFIAN PROJECT AS OPPORTUNITY FOR VALORISATION
}

\author{
Z. Barone ${ }^{\mathrm{a}}$, G. Nuccio ${ }^{\mathrm{b}, *}$ \\ ${ }^{\text {a} U n i v e r s i t a ̀ ~ d e g l i ~ S t u d i ~ d i ~ P a l e r m o, ~ D ’ A r c h ., ~ V i a l e ~ d e l l e ~ S c i e n z e, ~ E d . ~ 14, ~} 90128$ Palermo, Italia, zaira.barone@unipa.it \\ bUniversità degli Studi di Palermo, D’Arch., Viale delle Scienze, Ed. 14, 90128 Palermo, Italia, gaia.nuccio@gmail.co
}

\section{KEY WORDS: History, Virtual Restoration, Noto Antica, fruition, 3D recontructions, virtual museum.}

\begin{abstract}
:
The archaeological site of Ancient Noto is all that remains of one of the most interesting and important cities in the Est part of Sicily. Architecture and political life made Noto a point of reference for the island, expecially in XVI and XVII century, before it was destroyed by a devastating earthquake in 1963. A general project of safeguard, together with archaeological excavations, could hand a great amount of information, archaeological finds, pieces of architecture, that are useful to understand the site, known as a "Sicilian Pompei". Our intervention has the aim to describe the importance of EFIAN (Experimental Fruition Ingenious Ancient Noto). The project is carried out as a collaboration between Palermo University, Catania University, SIQUILLIYA s.r.l. and Service \& Advice s.r.l.. The project answers to the need of improving the valorisation of the site, according to the principles of Italian Code for Cultural Heritage and Landscape. EFIAN's purpose is that of improving public's sensibilisation, to open lines of research and restauration of monuments. The working method is based on the strong relationship established between History, Architectonic Relief, Restauration, and Study of ancient technics of construction linked to the territory. The research is supported by new generation technologies. Datas are used to build digital reconstructions of ruins in the shape of virtual anastylosis and digital reconstruction of whole buildings. Four different sites have been studied during the project development.
\end{abstract}

\section{Ancient Noto and Efian project. A conscious fruition for a real enhancement process}

\subsection{The city of Ancient Noto included in UNESCO World Heritage List}

The earthquake of 11th January 1693 in Val di Noto is considered as one of the most devastating disasters of Modern Age in Europe. Almost half of population in stroken cities died under the rubble and the amount of architectural heritage lost is shocking. After the catastrophe some destroyed cities were rebuilt in the original area, and some, instead, were founded again in a new site. The reconstruction of the new town of Noto took place in Meti valley, $10 \mathrm{~km}$ far from the original site on mount Alveria, and nearer to the cost. New towns of Val di Noto, rebuilt in a common architectural style, the so called late Baroque of the eastern part of Sicily, were declared Patrimonio Unesco in 2002 (cities included are: Caltagirone, Catania, Militello in Val di Catania, Noto, Palazzolo Acreide, Ragusa and Siracusa).

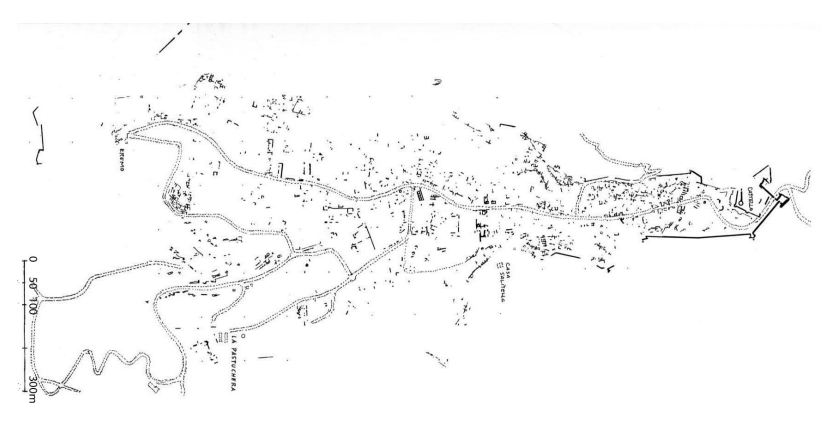

Figure 1. Ancient Noto, plan of emerging ruins. From Hofer (1997)
Before the earthquake Noto Antica was a rich and flourishing city. It was founded during the Norman domination, between, $\mathrm{XV}$ and XVII century, the city increased in richness, economical and political stability. It had several public buildings, religious buildings and numerous, impressive, residential buildings. Shortly before the fatal earthquake of 1693, Noto counted 26,000 inhabitants; due to the destructive event, population dropped down to 12,000 (Tortora, 1972). Ancient Noto was abandoned after the new foundation, exploited as an open air quarry of building material for the construction of Baroque Noto. The new city was founded seven kilometers away from the old one on a new site, for safety reasons and also due to a building ground more comfortable than the previous one: a place with all the characteristics to withstand futures earthquakes. Noto, like Ragusa Alta, Catania, Avola and Grammichele was built according to a new concept and it is undoubtedly one of the most interesting examples of XVIII century city in Sicily (Tobriner, 1989).

Reconstruction in the old site, now called Ancient Noto, was an impossible task. The city was located on a rugged hillside, its medieval streets were too narrow and the houses, built side by side, would have risked to collapse on each other, as happened in 1693. Furthermore great capitals would have been needed to make the place suitable for the reconstruction, since the piles of rubble were impressive and difficult to remove. Even today, 300 years after the destructive event, the piles of rubble are still visible, in their majestic size and heaviness, they continue to be a constant element of the landscape. The few archaeological investigations made in the XX century succeeded on unearthing only some areas from the rubble. When possible, excavations in areas of the Castle, of the Major Square and of the Jesuit College, have always yielded interesting informations about the history of the building hidden underneath the rubble. Some archaeological excavation took place in XX century, although with a range of interest limited to single areas or monuments.

\footnotetext{
* a. Zaira Barone, Phd in Conservation of Architectural Heritage. - b. Gaia Nuccio, Phd student in History of Architecture.
} 
Most of the ruins, not always identified, pour in a condition of neglect for a long time, leading to the loss (deterioration of materials and the plundering of archaeological sites) of finds and information. In sixties a plan was developed to protect the landscape of the whole area of Mount Alveria. Between 1974 and 1983 fields within the archaeological bond were bought, becoming State's property. The City, the Superintendent and the Province signed an agreement to create the Monte Alveria Park. But the park had great difficulties due to its size, the lack of electric light and its expensive maintenance requirements, hard to handle with such scarce economic resources. It was also highlighted the strategical need of a sustainable tourism enhancement plan, to guarantee more inputs and gaining political focus on the park. The goal was that of gaining necessary financing, facing the lack of a clear political strategy in manutention, preservation and fruition.Mount Alveria is framed by a very strong growing tourism market, related to Baroque cities of Val di Noto, but it is at the same time out of the touristic network, connecting points of interest like Ragusa, Modica, Scicli, Syracuse and Noto. Its geographical proximity should provide the right visibility, while nowdays it is considered as a trekking path, limited at least, to an approach with castle ruins (excavated and restored area, situated at the beginning of the crossing path of Ancient Noto) and, for interested tourists, through the city to the area of the Main square (which is only half the extension of the entire city). Moreover, the path is obliged along the still existing Main Street, the ancient main road through the town, branched addressing to the main square. It is today the only accessible way by car or by foot. It is impossible to cover secondary routes, perpendicular to the main road, because vegetation is very lush and does not allow the crossing and the vision of the emerging ruins. Builginds situated along the Main street (the castle and his chapel, the Jesuit college, the main square and the Carmel church), qualify the path as a great interest area. Equipped with the right amount of services for better enjoyment, the road could be included in cultural tourist path with the rest of the Val di Noto, becoming a real touristic focus for all the centers around. The raise of touristic promotion policies must by encouraged through the Val di Noto, establihing network policies and an enhancement of the area to make it more on focus, and to highlight the cultural values ruins represent.

Val di Noto (Unesco Heritage) is enriched each year of services related to tourism, public and private, because its combination of natural and cultural heritage, generates a fascinating and interesting land full of monumental architecture of high historical and aesthetic value. What makes Noto a case unique is the short distance between two cities, characterized by urban and architectural quality. One of them is Ancient Noto, destroyed by the earthquake of 1693 . It is a medieval urban structure, whose perimeter is still perfectly legible, as the perimeter of the castle and its magnificent ramparts, the Main Street, and the ruins of the most important monuments. Archaeological excavations could unearth still surviving ruins; but even without funding for excavations, just the use of virtual reality and the development of Baroque Noto's Civic Museum, preserving and exposing findings, it could give a clear boost to the understanding of what the earthquake destroyed but Time still preserves. Not far from the old town on Mount Alveria,it is possible to visit the new city, rebuilt in XVIII, offering one of the most interesting examples of Baroque Architecture in Sicily. (Z.B.)

\subsection{EFIAN Project (Experimental Fruition Ingenious Ancient Noto)}

Progressive evolution from the idea of "Monument" towards the idea of "Cultural Heritage", means to involve not only restoration experts but the whole community in Heritage preservation. Students, citizens and cultural associations should share the awareness of increasing importance of safeguard (Prescia, 2017).

A general project of safeguard, together with archaeological excavations, could hand a great amount of information, archaeological finds, pieces of architecture, that are useful to understand the site, known as a "Sicilian Pompei" (Tobriner, 1989). Our intervention has the aim to describe the importance of EFIAN (Experimental Fruition Ingenious Ancient Noto) financed by M.I.U.R. inside the "PAC. Avviso D. D. n. 436 del 13 marzo 2013" (Ministero dell'Istruzione, dell'Università e della Ricerca Italiano) as first place classified project in Italy "Linea 2- cultura ad impatto aumentato-spazi della cultura 2.0" in order to the safeguard and fruition of Ancient Noto. The project is carried out as a collaboration between Palermo University, Catania University, Siquilliya s.r.l. and Service \& Advice s.r.l.

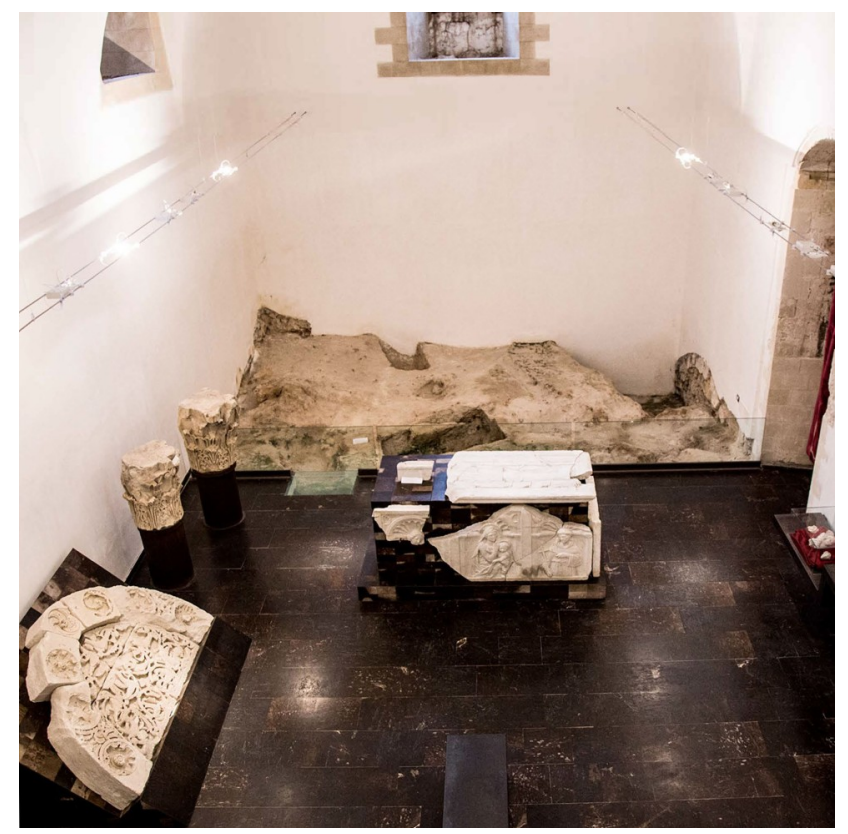

Figure 2. Noto, Civic Museum, Ancient Noto exposition Room.

Project answers to the need of improving valorisation of the site, according to the principles of Italian Code for Cultural Heritage and Landscape. EFIAN's purpose is that of improving public's sensitisation, to open lines of research and restoration of monuments. The project has a precise scientific aim: the increase, inside the archaeological site of Ancient Noto of touristic fruition.

The reason of the choice is that Ancient Noto is a well known site that is still few visited. EFIAN project is based on the development of two different but complementary systems of exposition. The first one in Baroque Noto and the second one on site (Ancient Noto):

1. A multimedia interactive exposition of researches products. Studies conduct under the project are set in the "Medieval Section" of the Civic Museum of Baroque Noto. This opening presentation inside the museum has the aim to arise the interest and the curiosity of tourists. They could this way be aware of the existing chance to reach and visit the ancient city. Moreover the Museum has now a permanent exposition of interesting architectural elements found in Ancient 
Noto.

2. Multimedia and interactive itinerary through the archaeological site provides a virtual immersive experience inside and outside the main destroyed monuments. 3D technology is able to superimpose to ruins an image of building's aspects before the day of earthquake (realized according to scientific studies).

The idea carried forward by the project in that of directing tourist that are visiting Baroque Noto to the site of Ancient Noto. This service can be identified as a cultural service before that a touristic service, for his worth of giving visibility to an almost forgotten reality. The hope is that of catching economic interests in order to improve projects of historical research, archaeological excavations and activities of restoration. Thanks to technology development, it is possible to dispose of innovative and non-invasive research tools. These allow a deep study of cultural heritage and facilitate data sharing and transmissions by assuring the conservation and fruition of artifacts, without the need of hard recovery system or building anastylosis. Thanks to Virtual Reality system improvement, digital reconstructions can be projected on ruins or visualized by displays of smartphones or tablets. Also the range of scientific applications have extended exploiting 3D reconstructions, in matter of knowledge and diagnostics of the state of artifacts, but also thanks to hypotetc rebuilding through virtual anastylosis, giving a primary importance to the understanding of the artifacts themselves as to their potential fruition and conservation. Interactive multimedia tour is articulated inside the archaeological area of Ancient Noto, where the main buildings that disappeared because of the earthquake are virtually reconstructed in their original place in urban contexts. Fruition of the site, supported by a careful teaching strategy, now consists in four display areas, where it is possible to "dive" through architectural settings that no longer exist with 3D technology, through the use of specific viewers. Val di Noto is justly famous for the amazing late-baroque cities that have enjoyed the prestigious inclusion in the World Heritage List. Less known, or given only to specialist research, it is the fact that this extraordinary artistic season had a medieval history that can now be reconstructed only in fragments, which disappeared as a result of catastrophic events. The city of Noto Antica still holds, under thousands of cubic meters of rubble, fragments of that time, made up of prestigious elements of architecture that often lie at the same points in which they ruined that evening of January 11, 1693. Buildings collapsed in 1693 are still buried under meters of rubble blocks and most of them have not been recovered because there was not a political will to fund the excavation but also because the city dimension is huge. The four sites chosen by Efian project have all been affected by excavations and partial recovery of decorated and valuable finds. Today many of these recovered items can be seen at the Civic Museum of Baroque Noto which is the link between the new city and the old city. The interactive multimedia exhibition is open to visitors in the "Sezione EFIAN" (EFIAN section) of the Civic Museum, which has been opened a few years ago and houses an important collection of sculptural and architectural elements from the ancient city. Multimedia installation is the first implementation phase of a larger project for a museum intended to guide the visitor to discover the artistic heritage of Ancient Noto and its historical context. It is important to prepare tourists before the visit to Ancient Noto, because at the arrival it is not possible to understand the size and impressiveness that the city used to have before the earthquake. Furthermore, those who visit this area of the Iblei, usually reaches first Baroque Noto and only then, if informed, could reach Ancient Noto. Currently Ancient Noto, due to the distance from the new city and to the kind of small, winding streets, can be only reached during the day, by car or by small buses. The project involves to create an association of local young people who could adress tourists to Ancient Noto, drive them to the site with small buses and guide them to the understanding of the huge archaeological area. Among the four sites chosen for virtual reconstructions there are some more complex to understand because their dimensions and the reduced number of ruins emerging from the ground. An example is the large main square of the city, known as Piazza Maggiore. In this case, researchers, after a survey on emerging ruins and comparison of data with historical and documentary information, took the choice of realizing the $3 \mathrm{~d}$ reconstruction only of external parts of buildings. The decision was dued to the lack of historical information and sufficient architectural elements that could support hypothesis of reconfiguration of the interior of monuments insisting on the square.

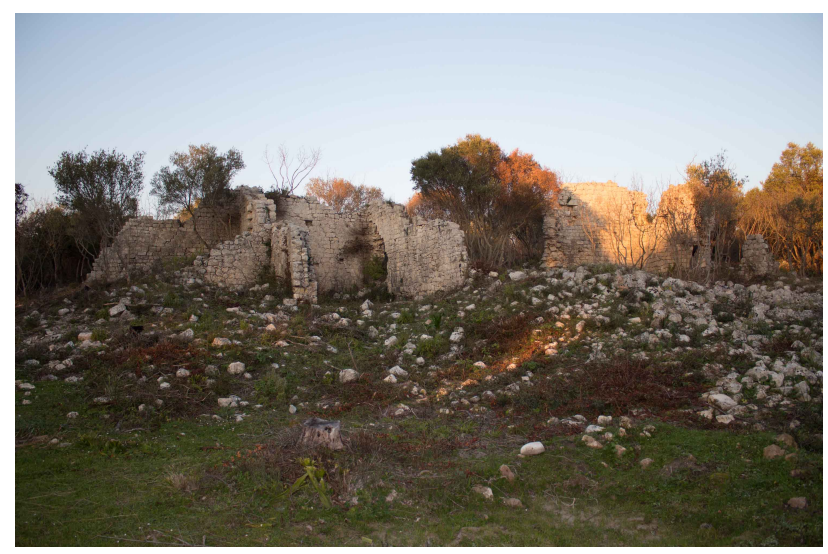

Figure 3. Ancient Noto (Sicily): site of the Piazza Maggiore (Main Square): ruins of the Senate Palace Ruins. Emerging ruins have been identified as interior walls.

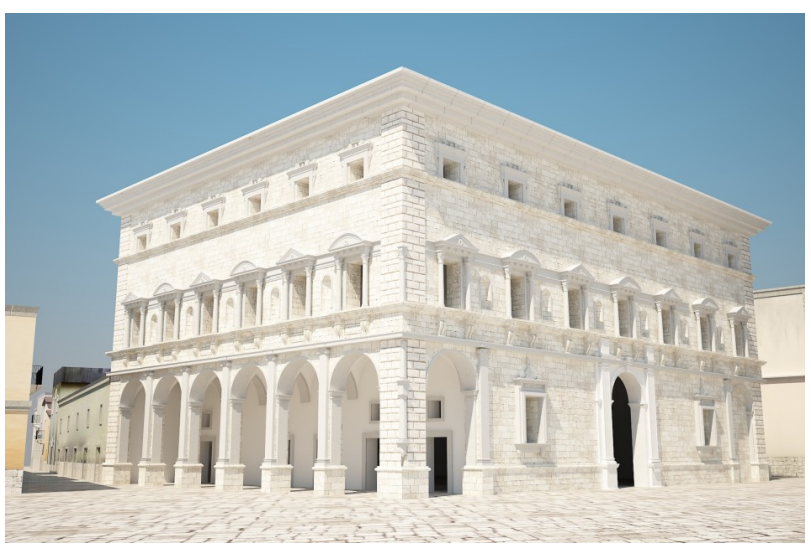

Figure 4. Ancient Noto (Sicily), site of the Piazza Maggiore (Main Square), digital reconstruction of the Senate Palace, (digital reconstruction by Z. Barone, rendering by G. Nuccio)

Piazza Maggiore was a big void inside the centre of the ancient city. Before 1693, the square was marked by two large monumental buildings: the Senate Palace, completed at the beginning of the XVII century, and the imposing Mother church, result of the stratification of many projects spanning from the Norman period to the XVII century. The Mother church had a compact prospect, typical of medieval churches throughout the South Italy. Some works of renovations were being undertaken when the Mother church was hit by the earthquake. Ruins of the buildings of some shops, were still 
visible in the space in front of the facade of the church, part of a "neighbourhood in front of the church" that was knocked down starting from 1580 to enlarg the square. The square was equipped also with a fountain characterized by sculptures of the group of the Laocoon. Filippo Tortora in his description of Ancient Noto portrays the fountain placed alongside the prospectus of the palazzo Senatorio (Tortora, 1712). It was possible to describe the spatiality of the square and the buildings that outlined the perimeter only thanks to an extensive work on historical texts and documents. The crossing of informations desumed by sources with data collected during the work of relief and with interpretation of construction techniques, enabled the forumulation of reliable hypothesis. Accomplished work on the fours selected sites, as well as in complex case of mother church, is always presented to visitors as a hypothesis, and never as a historical certainty. The goal of the project is not to present digital reconstructions as historical truth but tu use them as a support, providing the perception of what earthquake and neglect made incomprehensible in three hundred years. Although the perceived landscape appears as heaps of rubble with emergind ruins, sites are still felt in their monumentality, strongly keeping their historical values despite the loss of material data. (Z.B.)

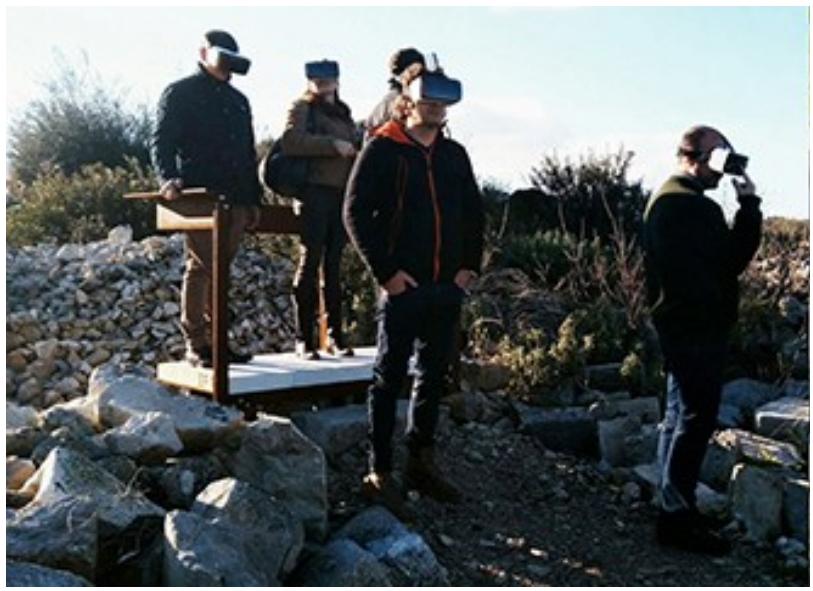

Figure 5. Ancient Noto (Sicily), ruins fruition with head mounted displays

\section{"Cultural accessibility" as a boost to the enhancement}

"La proiezione virtuale sull'oggetto restaurato traduce in termini figurativi l'interpretazione sull'esistente. Può essere più 'spinta' (in termini formali e cromatici) di quanto non sia consentito [...] al restauro 'materiale'. Può variare nel tempo, può meglio essere compresa da un largo pubblico, ormai maggiormente educato al linguaggio cinematografico (dinamico, transitorio, esplicativo) che a quello figurativo tradizionale (perlopiù fisso, permanente, implicito)" (Fiorani, 2014).

We are abruptly moving towards possible virtual reconstrucition of what has been lost in time, pursuing the ambitious task of illustrating, with didgital images, skills and overall contents of history and restoration studies. However it is important to underline that changements inrtest especially means and the way the method changes according to development of technologies, but the method of investigation itself keeps his logical process and strong attachment to material data of architecture. The new perspective is that of facilitating exchange of information between the parties, to widen the "cultural accessibility" to monuments as much as possible.
Today visitor and monument could both be considered as active subject of fruition activity because they interact dynamically. Fruition, especially of archaeological heritage, like the case of Ancient Noto, corresponds to a level of accessibility that does not deals with the mere enjoyment of places but involves meanings. This concept could be expressed by the words "cognitive or immaterial accessibility", namely the possibility offered by the well itself to be known and appreciated by very different types of users, sometimes regardless of the possibility of physical approach (Garofalo, Conti, 2012). Applications in architectural restoration and especially in management of monumental sites fruition highlights the complexity of the issue. The strength of this new way of enjoying archaeological sites and single monuments, has the goal to help visitors to understand as much as possible stratifications, constructive techniques, quality of materials, historical and aesthetic values of architecture. A new accessibility to historical and aesthetic values which can give everybody the opportunity to consciously benefit of cultural heritage under the guide of studies and scientifically correct illustrations. So a new type of fruition, no longer passive but as interactive as possible and subjected to a quick evolution. It can be considered not just a technological evolution, but a perceptive evolution of the way historical architecture can be enjoyed. Virtual reality does not claim to give final answers to history of architecture' s questions, but it wants to give reliable hypothesis to guide users comprehension. Final result of a research work concretizes only on a vitural multimedia platform avoiding every possible idea of architectures real reconstruction, false material, which today is hardly acceptable as a choice, in full respect of "real monument". Furthermore, data can be constantly updated, enriched or corrected, in the case new discoveries gave conflicting interpretations with previously obtained results. Enhancement of informatic equipments "veicola la sostituzione del reale con la sua rappresentazione, fino al punto di legittimare una forma di conoscenza che vede la sua principale finalità nell'interazione fra organismo percettivo (visitatore, turista, studioso) e realtà virtuale, di cui viene al limite anche accettata una ridotta 'fedeltà' al vero' (Fiorani, 2014). Actually theorists in restoration of architecture interrogate on cultural heritage fruition, because formulation of cultural heritage conscious fruition projects is also a matter of restoration. Need of comprehension and preservation of past traces has increased as well as the need of awareness relied to fruition, open to all king of visitors. Methods of restoration changed also for what concern the scale of intervention. Previously individual monument were the main focus of architectural restoration while now geographic context surrounding the building is object of attention as well (block, district, city, landscape) because context influence development of individual assets. The putting up on the net safeguard policies of the entire Val di Noto could bring benefits not only for Ancient Noto but also for all the cultural assets gravitating around. Accessibility intended as "cultural accessibility" is a contemporary requirement who also wants promote the understanding of links existing between architectural heritage in the same area. The demand from users has increased proportionally to the need of services within visited areas. This happens in museums, archaeological sites, in monumental architectural complexes which are not just monuments to admire but are a container of complex cultural projects. The effective development of services is a demande of users and a response of authorities. This is a contemporary matter that makes monumental complex productive and, the more fruition is appropriate to actual need, the more the good is enjoyed and sustainable for archaeological site. Enjoyment and attractiveness should never deny the high historical and artistic value which is conferred to monuments. Goal of productivity 
should never overcome values of cultural heritage, but objectives of monuments visitors awareness of importance and uniqueness of heritage should be exalted. Fruition project should be directed in this sense and towards sustainable solutions, expanded to as many users for maximum accessibility. Efian project is directed towards these new routes, and could be further extended, according to the awareness that Ancient Noto is a complex reality of difficult management. An alternative answer is required to give the site the right visibility in order to attract funding, thata are an unquestionable need to activate projects of mantainance, excavations, consolidations and widening of accessible paths of the Ancient town. (Z.B.)

\section{Investigation methodology, multidisciplinary method as base for digital reconstruction.}

\subsection{State of the art}

Digital reconstruction of destroyed or modified buildings as support to historical research is a praxis well developed during the last twenty years that allows to recreate the original appearance of architecture with a degree of precision directly proportional to available sources on the case study. Furthermore $3 \mathrm{D}$ reconstruction has revealed to be a powerful mean of investigation, able to give original answers to questions asked by researches. Best results are obtained by the recourse to a method combining strong attachment to sources (literature, documents, iconographical sources) and, when it's possible, to material data derived directly from architecture. The Architecture Department of Palermo University has played the task of realizing digital reconstructions of four principal sites of the destroyed town: the royal chapel of San Michele inside the castle of Noto; the church of Jesuits Order; the major square of the city including the Senate Building and the Mother church of San Nicolò and the Carmel church. Method of research was based on joined competences belonging to researchers from different scientific areas. Researchers in history of architecture worked together with experts of buildings restorations and experts in relief of Architecture, to accomplish a kind of research affected by numerous gaps, caused by the destruction of a huge part of documentary heritage and the town itself during the earthquake of 1693 . This paper has the aim to explain in detail the methodology adopted and its declinations according to the peculiarities of different cases study, in order to put on evidence the quality of results that could be obtained by newgeneration multidisciplinary approach to historical investigation. In a first step documental sources on which historical research is based will be identified and described. Than the paper will focus on multidisciplinary methodology and its declinations; finally new possible horizons of researches and valorisation development will be proposed. Historical research on architectural heritage of Ancient Noto has to overcome the exiguity of written and iconographical documents. Some written sources of XVI and XVII century survived as well as some pieces of literature describing the ancient city, redacted in the years immediately following the earthquake. Most of them are based on Vincenzo Littara's De rebus Netinis, written in 1593, that offers a precious chronicle of life inside the town in XVI century and on a manuscript that was found in XIX century inside the silver ark of San Corrado, the Patron Saint of the city. This is attributed to a religious man, Padre Tortora, and dated at 1712; it provides a description of Ancient Noto before and immediately after the earthquake: it is a narration that involves the vicissitudes of city's reconstruction. Another history of Noto, redacted in the same period, is instead anonymous. The masterpiece of the Sicilia Sacra Disquisitionibus et Nobis
Illustrata by Rocco Pirri redacted in XVIII century includes also a section dedicated to the churches of Ancient Noto's Diocese. It is finally important to mention a collection of documents concerning Ancient Noto's life called Libro Rosso. The original manuscript is now preserved inside the Civic Library of the Baroque city while some transcripts are available and recently a Regesto of the Libro Rosso has been published (Risino, 2003). For what concern Iconographic documents some, representation of the whole city drawed on XVIII century could me mentioned. They are considered by scholars reproductions of an original copy probably redacted before the earthquake by Padre Catone, member of Friars Minor Conventual of Noto, and unfortunately lost (Cugno, 1970). Between different exemplars preserved by public institutions and private families two exemplars are considered as the most significant for the good quality of representation of the city. The first one is now exposed inside the Civic Library of Noto and it is titled Prospetto della città vista da ponenete. It is a $185 \times 20$ $\mathrm{cm}$ drawing composed by a planimetry and a prospectus of Ancient Noto seen from a look-out spot situated on the West side of external walls. Two different legends below the drawings, one for the planimetry and one for the prospectus, allow the identification of buildings, associating each building to a number. A reference to the author of the copy is written in a caption between the prospectus and the legend. It deals with Padre Antonio Maria Tedeschi, Father of the Mother Church of Pachino between 1777 and 1822 (Cugno, 1970). It exists also a watercolours copy of Antonio Maria Tedeschi's work by Sgroi, realized in 1877 and exposed in the Civic Museum of Noto. A different plan of the city with legend survives only thanks to some photographic reproductions, because of the loss of the original one, probably belonging to Trigona Hospital in Noto. Inside the cartuouche it is possible to read the dedication to Illustrissiomo D. Pietro Maria Di Lorenzo Signore di Binovini, from 1750 one of the juryman of Noto (Cugno, 1970). Both these illustrations are considered by scholars as reliable representation of the spatial planning of Ancient Noto in XVII century; dating could be justified with the presence of buildings erected in the early 1600' like the Jesuit's Order College.

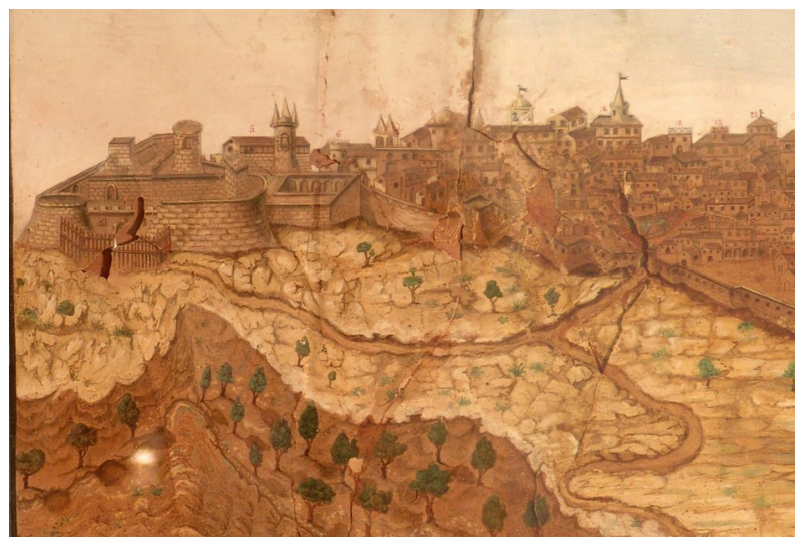

Figure 6, Detail of Sgroi's watercolor,on the basis of A. M. Tedeschi Prospetto della città vista da ponente.

During the reconstruction of Noto in Meti valley, a location nearer to the sea, ruins of the Ancient town castled on Alveria Mountain became a quarry for building material, especially cutting stone. Afterwards the Ancient town dwelt abandoned and almost forgotten for about two hundred years. Only at the beginning of $\mathrm{XX}$ century the rediscovery of this huge architectural and cultural heritage became a priority for Baroque Noto's inhabitants and started to fascinate researchers as well. 
The first official campaign of archaeological excavation was taken over by Santocono Russo and financed by Superintendence of Monuments. Fundamental was the contribution and the campaign of sensitisation taken over by local historians and archaeologists, taking to the foundation of I.S.V.N.A. (Institute for Study and Valorisation of the Antiquities of Noto) in 28 th January 1970. The aim of the Society was to sensitize both Authorities and citizens to the safeguard of cultural heritage of ancient Ancient town, the promotion of campaigns of excavation and restoration of monuments and the development of a controlled touristic fruition of the archaeological area, together with the preservation of the rich natural ecosystem. Annual publication of ISVNA, Atti e Memorie, can be considered as one of the most important sources of XX century, collecting researches on Ancient Noto's life and artistic, architectural and cultural heritage. In The Origin of Noto Stephen Tobriner (Tobriner, 1989) dedicates a section to the disappeared city. He illustrates the long debate that took to the decision of abandoning the old site on Alveria Mountain and choice of the new site for settlement. Important historical investigations have been recently carried out by Palermo University researchers and affiliated scholars. Especially works by Marco Rosario Nobile (Nobile, 2006) could be mentioned as well as studies by Maria Mercedes Bares (Bares, 2016), and by the local historian Antonello Capodicasa (Capodicasa, 2015) It is finally relevant to mention results obtained under the EFIAN project for what concern Noto's Civic Archive investigations. A document attesting the involvement of the Tuscan architect Francesco Buonamici ${ }^{1}$ in a renewal and enlargement project for the Anciet Noto's Mother Church in the half of XVII century witnesses that documentary historical studies on this matter are still an open field (Manfrè, 2016). (G.N.)

\subsection{Previous interventions and Efian methodology}

Historical researches, campaigns of sensitisation carried out by I.S.V.N.A. together with Noto's authorities, different punctual campaigns of excavations (Santocono Russo, 1971) together with safeguarding parts of destroyed architectures and artifacts, identified for their artistic value, inside the Civic Museum of Noto, moved in the direction of rediscovery and safeguard of such a huge and forgotten cultural heritage. However those initiatives with a common intent lacked joint actions that could promote touristic fruition of archaeological area and contemporary activate a virtuous circle of preservation and new historical and archaeological research in Ancient Noto. In this sense Efian project may be considered as a first step to fulfil this goal, with interrelation between joined competences of different partners. In the specific case of activities pursued by the Department of Architecture of Palermo University, 3D reconstructions were realised by a team putting together multidisciplinary competences of researches, together with a company operating in the field of relief and 3D visualization, disposing of advanced instrumentation. Research method developed in different and consequential steps. The first step was that of fixing the main goal: the accomplishment of 3D

\footnotetext{
${ }^{1}$ Tuscan architect famous for his works in Jesuit's building sites in Malta and many Sicilian cities. About his career see M. R. Nobile, Francesco Buonamici e la Sicilia, in G. Cantone, L. Marcucci, E. Manzo, (a cura di), Architettura nella storia. Scritti in onore di Alfonso Gambardella, vol. I, Milano, 2007, p. 265 e nota n.16.; C. Thake, Francesco Buonamici (1596-1677). A pioneer of Baroque Architecture in Malta and Siracusa, in Annali del Barocco in Sicilia. 2. Studi sul Seicento e Settecento in Sicilia e a Malta, Roma, 1995, pp. 19-30.
}

digital reconstructions available for an interactive navigation in situ, by the mean of 360 degree immersive panormas of architectonical objects running on specific application for new generation mobiles and projected in an immersive experience by 3D head mounted displays. The second step concerned the collection of data. Literature together with available written and iconographical documents were on Ancient Noto were collected and organized in online database disposable for Unipa project's members. Approach to ruins of the four site object of the study played a fundamental role in the development of researches. Collection of metrics data was achieved during different inspections and campaign of reliefs. First investigations had the aim to get researchers accustomed with ruins, visualizing dimensions of areas to investigate, identifying different conditions and issues for each building, taking the first hand made measurement and fixing the situation of decorated finds. These preliminary activities gave researches the required acknowledgement to best orientate the subsequent acquisition of metric and photographic data with instruments like laser scanner, remote-controlled drone, cameras and GPS equipment. Relief activities were preceded also by a campaign of puntctual cleansing of interested areas by the surplus of vegetation totally surroundings ruins that interfered with the fruition of artifacts. Different methods of relief were experimented according to dimensions of finds and required products. Remote-controlled drone realized a series of aerial photos following trajectories parallel to the ground surface. High-resolution photos underwent a process of stitching in order to obtain four highresolution orto-photos of the different sites. Laser-scanning of pieces of masonry allowed the digitalisation of ruins creating cloud points composing the basis for digital modelling. Markers point were positioned for laser scanning activities and identified by GPS coordinates in order to create a grid of orientation for point clouds. Finally isolated and decorated finds were object of photographic sets in order to create some clouds of points by the mean of photogrammetric relief. At the same time the estate of masonry was studied by an expert in restoration of architecture with the aim of indentifying stratification dued to different phases of construction of destroyed buildings. Collection of data was followed by the elaboration phase to set up solid basis for 3D modelling. By the stitching of photos taken by the radiocontrolled drone's camera it was possible to achieve very highresolution orto-photos of the four sites. Geo-referenced cloud of points were rototraslated and scaled according to GPS coordinates and measurement taken as reference on site. Metric analysis of points clouds provided dimensional points of reference for the development of $3 \mathrm{D}$ reconstructions. Afterwards decorated finds were meshed using software based on multi photo matching approach, obtaining high-resolution textured models with high-quality details of ornaments and reliefs. These were in a second step optimized to run on 3D modelling software keeping their textures. 3D modelling was the most delicate phase. Researchers reprocessed point clouds data to match achieved information with directions derived from written and iconographical sources and, at the same time, with analysis of masonry. Different work methods were undertaken according to the issues of each case. (G.N.)

\subsection{Area 01 Church of San Michele inside the Castle}

The church of San Michele, considered as a Palatine chapel of the castle, is the most famous and studied building, unearthed by different campaigns of excavation. The construction was probably begun in 1100 according to Conte Ruggero's wish; construction interventions are attested until XVI century when lateral naves were covered with cross vaults (Bares, 2012) San Michele chapel is characterized by a quincunx system with 
quadrilobati pillars. It was accessible by two monumental portals: one on the southern side, probably a direct passage to the castle, and the other situated in the western wall. In this case the mainly used method is that of virtual anastilosys for the considerable amount of decorated and sculpted stones whose location within the chapel is easily identifiable. Some of the finds had just been withdrawn from the archaeological area and preserved inside Civic Museum of Noto, providing an hypothesis of reconfiguration of western portal bazel. Virtual anastilosys approach is based on spatial repositioning of $3 \mathrm{~d}$ models of different finds that had previously been meshed, textured and optimized. This technique allows to recompose entire parts of architectures, for San Michele Chapel the two portals, the basement and some pillars, integrating gaps with hypothesis derived from documents and comparative approach with similar buildings. Both interior and exterior of the church were object of 3D reconstruction. Texturing of model was realized with texture created by high-resolution photos of existing masonry and some generated by laser scanning process. In this case virtual anastylosis is usefull to create a further link between archaeological site of Ancient Noto and the exposition of Civic Museum of Baroque Noto. Virtual repositioning of Museum's finds 3D models in chapel's digital reconstruction should provide a better comprehension of Civic Museum's exposition. Furthermore some images of digitally reconstructed buildings are still available in EFIAN room inside the Museum. (G.N.)

\subsection{Area 02 Church of Jesuit's Order}

Ruins of Jesuit Church could be found in two near sites, separated by dense vegetation. The first group stands along the main street and includes the basis of two pillars still preserving their cutting stone cover with well legible moulding. Some pieces of masonry clearly not belonging to the Church stand on its site and some exhibits with different decorative motifs are left on the groud. Relics of cross pillars and of the apse are located in a zone behind. One of the cross pillars still stands until the high of 2,5 meters, keeping its original aspect. Thanks to the discovery of facing pillars' basis it was possible to measure the hypothetical diameter of the dome.

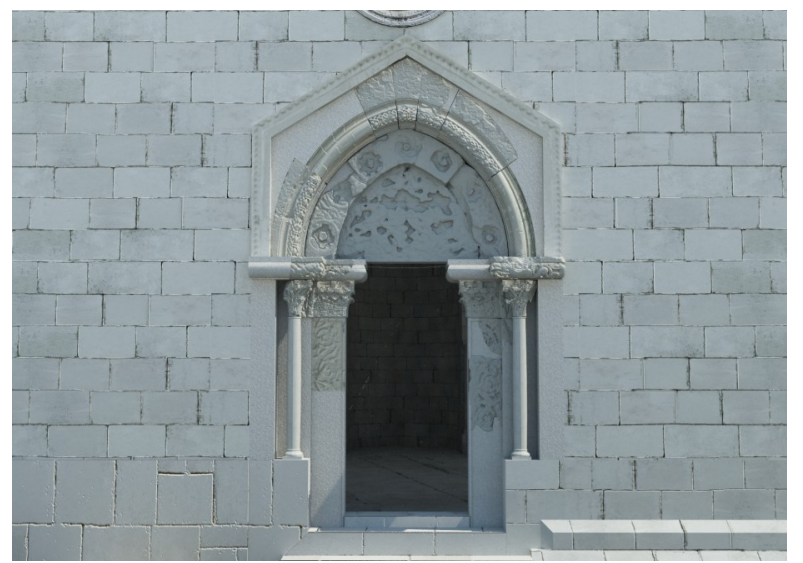

Figure 7, Western portal of Saint Michele's chapel, (digital reconstruction by F. M.Giammusso, rendering by G.Nuccio)

What strikes is the dimension of ruins. Multi faced pillars are extraordinarily massive, built to bear the weight of a 8 meters diameters dome. The church would probably have been one of the greatest of the Oriental part of Sicily, as well as an interesting example of Jesuit's architecture. Documental sources on Ancient Noto give little information on this building: Jesuit's College is described as one of the most representative building of the city, built since the early years of XVII century while Church's construction wasn't undertaken until 1634. Moreover iconography always shows the facade of the College but never that of the Church.(Tortora, 1972) Researches on Jesuit's Church benefited of specific documentary sources belonging to Jesuit's Order archival collections preserved in Rome, Malta and Paris (Lima, 1996). They consist of many plans of church and college and some exchange letters between the Padre Generale of the Order and visitors sent to verify the estate of construction site. Drawings are dated by scholars between 1602 and 1638; some of them are signed by Natale Masucci, architect of the Company, but the majority is anonymous. Visitors' letters describe complex vicissitudes involving the construction of the Church, whose site was changed at least three times because of disagreements between some local nobles and the Jesuits. Crossing achieved information with data collected by ruins it was possible to understand the story of Jesuit's Complex, hypothesizing that the ambitious project of the Church, definitely set up in 1634 was never accomplished.The comparison between the orto-photo of the site and a plan of the Jesuit Complex revealed that the new building was being constructed above northern part of the College, by demolishing it. This revelation explains the presence of pieces of masonry unrelated to church's project. Furthermore, during architectural relief operations, two decorated basis of a portal were found. These, such as a wall standing on the front side of archaeological area, belonged to a little chapel used by Jesuit in expectation for the construction of the new huge church. Although at the date of the earthquake the church was not accomplished it was not possible to detect the estate of construction in 1693. It was taken the choice to undertake 3D reconstruction of not accomplished church interiors. The plan was designed on the basis of existent ruins, while elevation was studied in comparison with other relevant examples of Jesuits Architecture in Sicily, like Jesus Church in Casa Professa of Palermo and Jesuit Church of Rome. For these reason 3D model was textured using a neutral white texture, simulating white plaster, with the aim of letting visitors understand the abstraction degree of choices carried out by researchers. Furthermore neutral texturing in combination with natural light condition simulation contribute to exalt volumes relief and decorative system of the model. (G.N.)

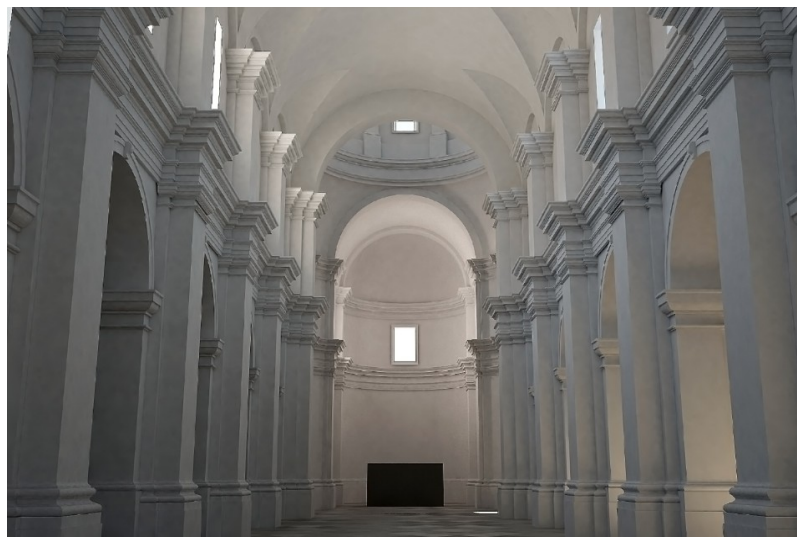

Figure 8, Jesuit Church, interior view (digital reconstruction by G.Nuccio, rendering by G.Nuccio)

\subsection{Area 03 The Major Square}

Investigation of the major square of Ancient Noto was a wide 
research, dealing with the investigation of two of the most representative buildings of the city: Senate Palace and the Mother church of Saint Nicolò. Surrounding system of houses and shops insisting on the perimeter of the square was at the same time modelled. Furthermore ruins had been subjected to little works of excavations and their poor estate complicates the detection of buildings plans. Analysis on ruins' clouds of points, with the aim of identifying building's entrance levels, revealed that the floor of the square was not planar but characterized by a lope rising toward Mother church's apse. Once approximately delineated square planimetry with brief plans of buildings, the work of reconstruction focused on external parts of buildings and was based mainly on information derived by written and iconographical sources (Focus could be found in 1.2 Efian Project). Senate Palace is portrayed as a three or four elevations building with the Five Architectonic Orders decorating facades (Tortora, 1712). In order to formulate a reliable hypotesis for its external structure and decoration, examples of Vermexio palace in Siracusa (Sicily), Municipal Building of Alcamo (Sicily) and Tarugi palace in Montepulciano (Toscana) were analysed in detail. Church dedicated to Saint Nicolò always appears in iconographic documents of Ancient Noto with a simple and impressive facade above a staircase, with one or two bell towers behind. The church underwent a long layering process of architectonic interventions during the centuries, non yet came to an end in 1693. According to recently found documents (Manfrè, 2016) a new greater project began to be built few years before the earthquake; this justify the choice of surrounding 3D model of the church's transept and apses with a huge stone structure. No decorated finds attributable with certainty to one of the buildings was found on site. However two stylophores limeston lions, probably belonged to a porch framing the main portal of the church of Saint Nicolò are preserved in Santissimo Crocifisso Church in Baroque Noto. Lions were digitalized by photogrammetric technical for artifacts relief and textured, optimized models were inserted in 3D building reconstruction. Textures were realized by high-resolution photos of masonry, when available, in other cases, such as church facade and square pavement they were supposed according to a comparison study of similar architectonic examples. (G.N.)

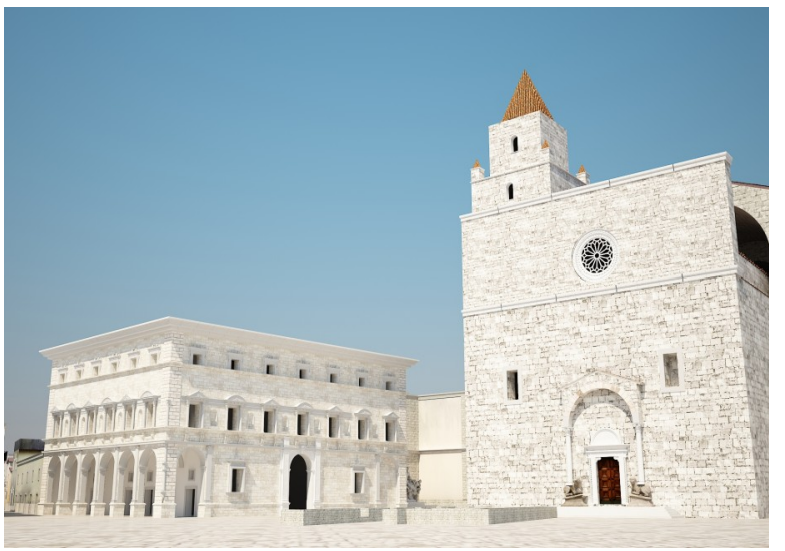

Figure 9, Senate Palace and church of Saint Nicolò (digital reconstruction by Z.Barone, rendering by G.Nuccio)

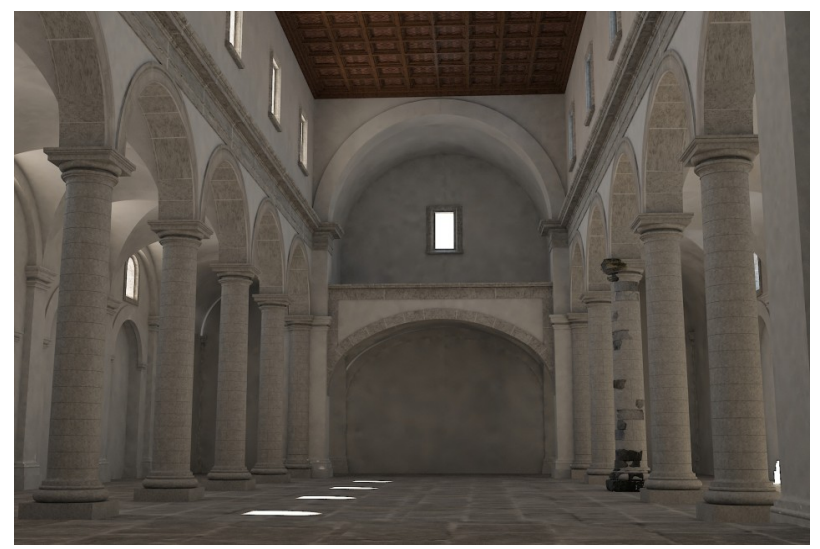

Figure 10, Church of Carmel, interior view (digital reconstruction by F. M. Giammusso, rendering by G. Nuccio)

Carmel order was founded in Noto at the beginning of XV century and settled ih the church of S. Giacomo extra moenia. Carmelitans acquired the old church of san martino in 1528 when started a work of total renovation of the building. They moved to the site only in 1578 (Guastella, 1973-74). The treenaves latin cross church supported by massive columns was probably mainly covered by a wooden roof except the center of the cross domed with a stone Sicilian dome on angular pendentives. Digital reconstruction of the building represents another important example of virtual anastylosis mainly focused on virtual reconfiguration of columns. Carved stones halfcylinder shaped composing the columns, called rocchi, are still lying on hearth and they were never restores. It is possible to identify a number engraved on their lower side, referring to the order of positioning in the shaft of the column. Also parts of capitals of columns were found between the ruins. Mesh created by laser scanning opertions gave the possibility to identify them by their number and to virtually reassemble at least one column that worked as a model of study. Proportions, entasis ,tapered sections. typology of the capital made possible to approximate the model column to the theoretical reference of Vignola's five orders treaty. Model column was integrated inside 3D reconstruction of the church and made distinguishable for keeping his own texturing of left-outdoor stone. Other columns were modelled according to its shape and proportions and the whole proportional system of the church was based on Order's one as well. Texture of the pavement were created on the basis of the matching of high-resolution photos of the still existing floor (it was not possible to recreate the appearance of the several decorated tombstones nestled on the floor that had been stolen), while the walls have been hypothesized covered by a light yellow plaster, made with dust of local yellow limeston. (G.N.)

\section{ACKNOWLEDGEMENTS}

Section 1 (Ancient Noto and Efian project. A conscious fruition for a real enhancement process) Author: Zaira Barone. Section 2 (Investigation methodology, multidisciplinary method as base for digital reconstruction.) Author: Gaia Nuccio

\subsection{Area 04 Church of Carmel}

\section{REFERENCES}

Mercedes Bares M., 2016. Il mondo della costruzione a Noto in età moderna, Palermo. 
Mercedes BaresM., 2012. La cappella reale di San Michele nel castello di Noto Antica (XII-XVI sec.), Quaderni di Lexicon, n.3, Palermo.

Capodicasa A., 2015. Storie di Noto Antica tra XV e XVII secolo, Avola.

Cugno L., 1970. Per una valutazione della pianta del padre Antonio Maria Tedeschi, in Atti e Memorie I.S.V.N.A., n I,, pp. 99-107.

Dato G., 2003.Da Beirut a Noto. Patrimonio archeologico e pianificazione urbanistica. Studi e ricerche nei paesi del Mediterraneo, Cannitello.

Fiorani D., Materiale/Immateriale: frontiere del restauro, in Materiali e strutture: problemi di conservazione. Nuova serie, Anno 3, N. 5-6, p. 9-23.

Garofalo I., Conti C., 2012. Accessibilità e valorizzazione dei beni culturali. Temi per la progettazione di luoghi e spazi per tutti, Milano.

Guastella S., 1973-74. Documenti inediti sul Carmine di Netum, in Atti e Memorie I.S.V.N.A., n.IV-V, Noto. pp.90-91.

Hofer P., 1996. Noto, Idealstadt und Stadtraum im sizilianischen 18.Jahrhundert, Zurich.

Lima A.I., 2001. Architetura e urbanistica della Compagnia di Gesù in Sicilia, Palermo.

Manfré V., 2016. Il progetto di Francesco Buonamici per la Chiesa Madre di San Nicolò a Noto Antica, in «Lexicon, Storie e architettura in Sicilia e nel Mediterraneo», n. 22-23, Palermo, pp.138-143.

Nobile M.R., 2006. Matteo Carnilivari e Pere Compte, 15062006, Palermo.

Pirri R., 1977. Sicilia Sacra Disquisitionibus et Nobis Illustrata, Palermo 1733. Section dedicated to Churches of Noto's Diocese was translated and published by F. Balsamo, under the title Chiese della Diocesi di Noto (dalla Sicilia Sacra.), Noto.

Prescia R., 2016. Comunicare il Restauro, in RICerca REStauro, Sezione 4 (a cura di R. Prescia), Valorizzazione e gestione delle informazioni, Roma, pp. 867-877.

Risino E., 2003. Il regesto del Libro Rosso dell'Università netina, Avola.

Tortora F., 1972. Breve Notizia della città di Noto prima e dopo il terremoto di 1693, (1712 ca.), C. Bonfiglio Piccione, Noto, 1891. and also an adition by F. Balsamo in, Noto. 